\title{
MUNICIPAL AVALANCHE ZONING: GONTRASTING POLICIES OF FOUR WESTERN UNITED STATES COMMUNITIES
}

\author{
By Arthur I. Mears \\ (222 East Gothic Avenue, Gunnison, Colorado 81230, U.S.A.)
}

\begin{abstract}
Four communities in the western United States (Vail, Colorado; Ketchum, Idaho; Ophir, Colorado; and Juneau, Alaska) have detailed avalanche-hazard mapping available. In response to this detailed information, Vail restricts building in a red (high hazard) zone but permits specially designed buildings in the blue (moderate hazard) zone. Ketchum allows single-family dwellings in red or blue zones regardless of design but will not permit such structures to be rented from the period ${ }_{15}$ November through I5 April of each year. Multi-family dwellings in Ketchum hazard zones must be designed for avalanche forces. Ophir will restrict buildings from the red zone and permit specially designed structures in the blue zone. Juneau does not restrict development in any avalanche-hazard zone.

RÉsumé. Zonage municipal des avalanches: comparaison entre les politiques de quatre communes de l'Ouest des États-Unis. Quatre communes de l'Ouest des États-Unis (Vail, Colorado; Ketchum, Idaho; Ophir, Colorado et Juneau, Alaska) disposent de cartes détaillées de risques d'avalanches. En fonction de ces informations détaillées, Vail interdit la construction dans la zone rouge (fort danger) mais autorise des constructions d'architecture spécialement conçue dans la zone bleue (danger modéré). Ketchum autorise des constructions individuelles (une famille) dans les zones rouges et bleues quelle que soit leur conception architecturale mais en interdit la location entre le ${ }_{1} 5$ Novembre et le ${ }_{1} 5$ Avril. Les habitats destinés à plusieurs familles dans les zones de risques à Ketchum doivent être construits de manière à résister à l'impact des avalanches. Ophir restreint la constructibilité des zones rouges mais autorise des architectures spécialement conçues dans les zones bleues. Juneau n'impose aucune restriction au développement urbain dans aucune zone de danger d'avalanche.
\end{abstract}

Zusammenfassung. Lawinenzonung für Stadtgebiete: Gegensätzliches Vorgehen von vier Gemeinden der westlichen USA. Vier Gemeinden der westlichen USA (Vail, Colorado; Ketchum, Idaho; Ophir, Colorado; Juneau, Alaska) verfügen über detaillierte Karten der Lawinengefährdung. Entsprechend der hohen Informationsdichte schränkt Vail die Bautätigkeit in einer roten (stark gefährdeten) Zone ein, lässt jedoch Bauten mit Spezialkonstruktion in der blauen (mässig gefährdeten) Zone zu. Ketchum genehmigt Einfamilienhäuser unabhängig von ihrer Konstruktion in roten und blauen Zonen, gestattet aber keine Vermietung solcher Bauten in der Zeit vom 15 November bis 15 April. Mehrfamilienhäuser in Ketchum müssen in Gefährdungszonen gegen Lawineneinwirkung abgesichert sein. Ophir verbietet Bauten in der roten Zone und gestattet Spezialbauten in der blauen Zone. Juneau kennt keine Einschränkungen in irgendeiner Zone mit Lawinengefährdung.

\section{INTRODUCTION}

Snow-avalanche zoning can have its greatest effect on land-use controls and property values at the municipal-government level because within the boundaries of communities property values are highest and human activity is most concentrated. In contrast, within the western United States, avalanche zoning on the county, regional, state, or national level would have little practical use and, in general, has not been attempted because large percentages of mountain terrane are controled by public, rather than private interests and are not available for private development. Furthermore, the mapping of avalanche-hazard areas on a small scale ( $\mathrm{I}: 24$ ooo is the map scale generally available with most detail), for recreational activity, such as the winter use of the back-country, is not useful for the backcountry tourist. Winter recreationalists should be aware that avalanche-hazard intensity varies with time throughout the season, depending on prevailing weather and snow-pack conditions.

This paper contrasts the policies and zoning ordinances of four western United States communities with respect to snow-avalanche hazard mapping and land use in avalanche paths. Two of these towns (Vail and Ketchum) have similar physiographic and socio-economic factors: 
I. An active ski industry provides the stimulus for rapid economic growth.

2. Vigorous real-estate speculation and development attracts a wealthy population and results in high land values.

3. Design-magnitude avalanche return periods are long compared with the residence time of most of the population.

4. A large amount of valuable land is located in avalanche paths.

5. The local government desires to warn and/or otherwise protect the public in avalanche areas.

6. Detailed avalanche-hazard mapping is available.

The two other towns considered in this paper do not have a large dominant ski industry, although ski areas exist nearby, and do not have very large land values because of resort development. However, these towns are similar in other respects and have serious avalanche hazards. They are included for comparison.

Despite the similarities noted, significant differences exist between these communities in their responses to the problems related to avalanche zoning.

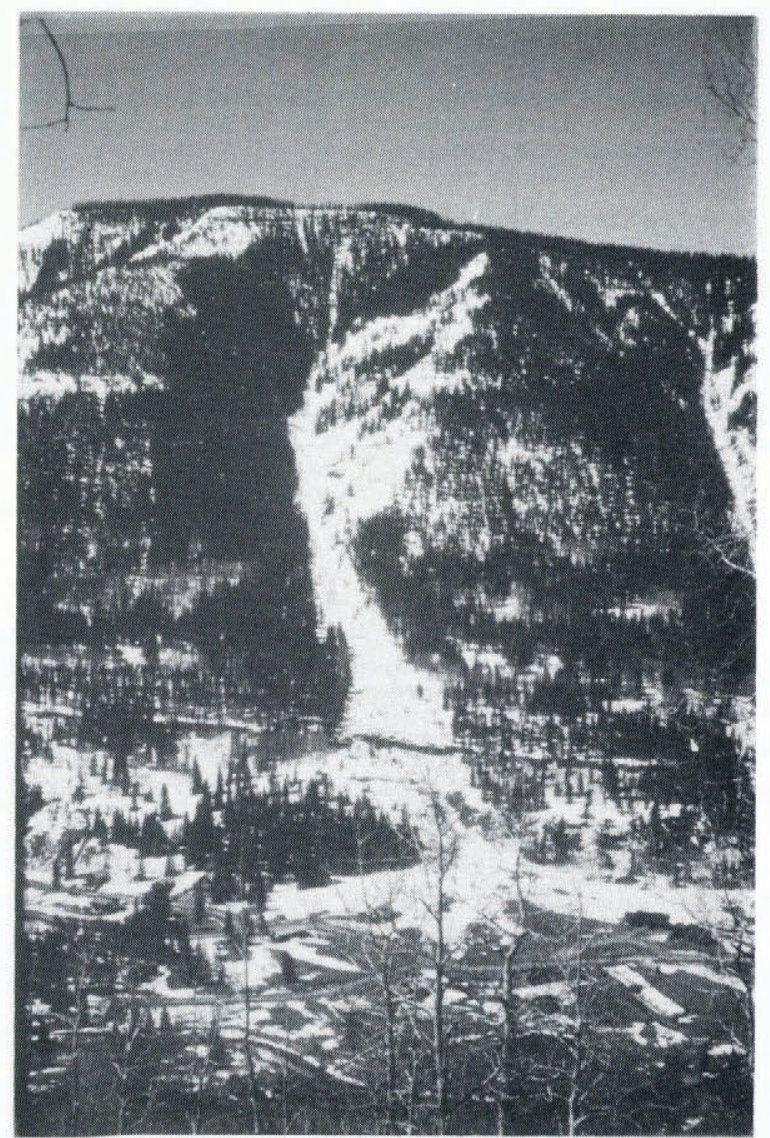

Fig. 1. The King Arthur avalanche path in East Vail produces wet and dry flowing avalanches and powder avalanches. Total vertical relief in this avalanche path is approximately $700 \mathrm{~m}$. 


\section{Case examples}

\section{Vail, Colorado}

Vail is located at an elevation of $2500 \mathrm{~m}$ in the Gore Range of central Colorado and was founded as a resort community in 1962 . Previous to the development of the town, the valley of Gore Creek, in which Vail is located, was sparsely populated and very few well-documented reports of large avalanches exist. No large avalanches have been observed since the founding of Vail. In 1975 the municipal boundaries were extended approximately $15 \mathrm{~km}$ eastward into an area previously zoned by the Eagle County government for residential development. This East Vail area also has the greatest avalanche hazard as the run-out zones of several major avalanche paths and many minor paths extend into privately owned property (Fig. I).

During the period $1970-75$, various unpublished studies of selected avalanche paths were conducted by the district office of the U.S. Forest Service, by the University of Colorado, Institute of Arctic and Alpine Research (Ives and Krebs, 1978), and by several private consultants. These studies ranged in detail from casual assessments of the snow avalanche potential, to detailed studies of the magnitude-frequency relationships of selected paths. The studies gave information not previously available to the Eagle County and town of Vail governments and provided a basis for the establishment of avalanche-hazard zones. In response to this new information, Vail formulated a comprehensive avalanche land-use plan that, in some cases, alters the zoning previously established by the Eagle County government prior to annexation by Vail. The essential points of the Vail avalanche-zoning plan, which, in some cases severely limits the property owner's use of his land, are summarized below:

a. At town expense, consultants (LaChapelle, unpublished; Mears, unpublished), mapped "avalanche influence zones" (AIZ), which are defined as areas in which avalanches may but do not necessarily constitute a hazard. The AIZ (Fig. 2) are not defined by any analytical techniques (e.g. Sommerhalder, i 966 ; Mears, i976; Leaf and

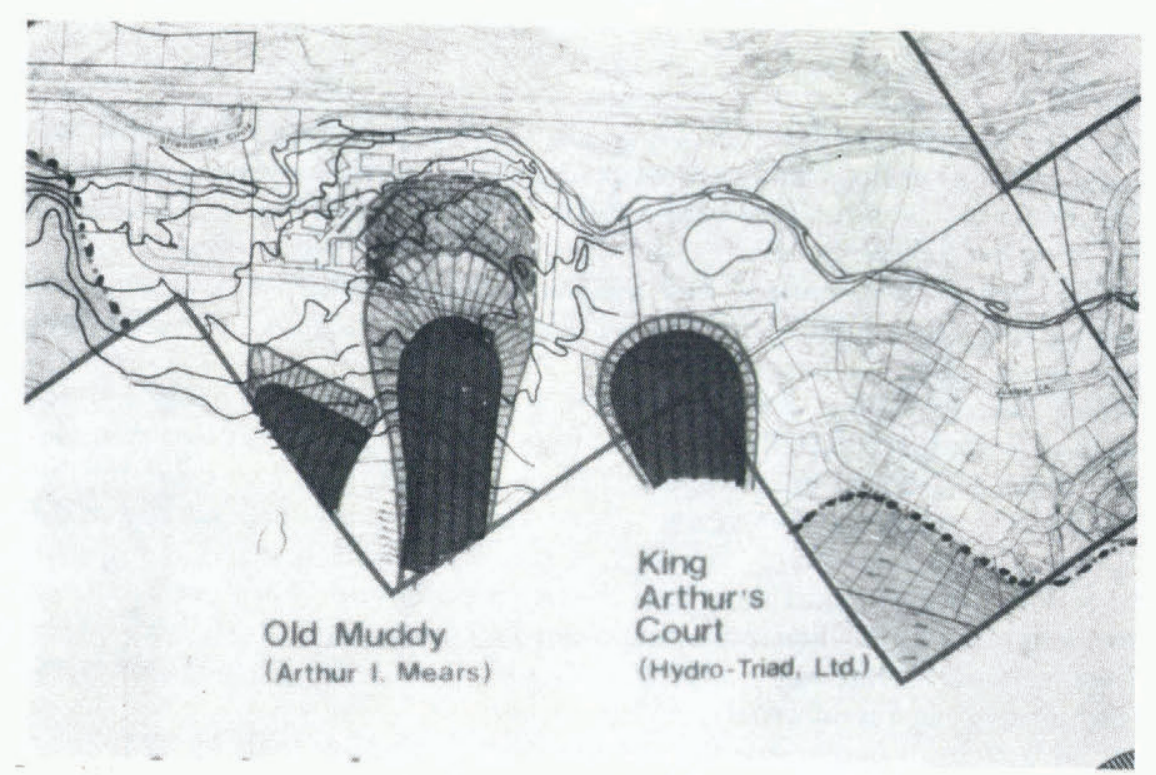

Fig. 2. This portion of the Vail avalanche zoning map shows a part of the AIZ specified by the town of Vail and outlined by a dashed line, and two site-specific studies done by private consultants. The site-specific studies subdivide the avalanche hazard into two or three zones of intensity, based on expected frequency and dynamic pressure. 
Martinelli, I977) but instead are qualitative assessments of the hazard, based in part on the studies referred to above that were conducted between 1970 and 1975. Building permits are not issued within an AIZ unless more detailed studies are completed.

b. If property lies within an AIZ and a building permit is desired, the property owner must determine, at his expense, the details of the design-magnitude avalanche that must be considered in zoning and structural design. This detailed study must, according to Vail ordinance, specify red (high hazard) and blue (moderate hazard) zones, and these zones must be established through application of analytical techniques; dynamic pressures must be computed. The red and blue hazard zones are defined by Vail ordinance as follows:

In the red zone, impact pressures on a flat surface normal to the flow exceed $600 \mathrm{lb} / \mathrm{ft}^{2}$ (approx. 2.9 tonnes $/ \mathrm{m}^{2}$ ) and/or the avalanche-return period is less than 25 years. Residential construction is not permitted in the red zone.

In the blue zone, impact pressures on a flat surface normal to the flow are less than $600 \mathrm{lb} / \mathrm{ft}^{2}$ (approx. 2.9 tonnes $/ \mathrm{m}^{2}$ ) and return periods are 25-100 years, approximately. Building is permitted in the blue zone if design for avalanche forces is provided by an engineer registered in the State of Colorado.

Two important points are implicit in the Vail avalanche-zoning plan. First, in order for an engineered structure to be built, avalanche-design criteria, specifying velocity, density, flow height, and type of avalanche, must be provided to the engineer. Although it is not possible to predict such design criteria with a high degree of reliability at the present time, it is important that the property owner or his consultant can show that he used the most reliable methods presently available to derive the design criteria. Secondly, because responsibility for providing safe design lies with the property owner or his consultant, it appears that the town of Vail is relieved of such responsibility. However, the location of the burden of responsibility has not yet been established in the courts.

The Vail avalanche-zoning plan has been working smoothly since 1976 .

\section{Ketchum, Idaho}

Ketchum is located at an elevation of $1700 \mathrm{~m}$ near the Sun Valley ski area in south-central Idaho. Severe hazard from avalanches with long return periods exists in the Warm Springs area of Ketchum (Fig. 3) and in several additional areas within the city boundaries. Major avalanches have been observed during the last 30 years and one building in Warm Springs was destroyed by avalanche impact. Despite avalanche awareness among some residents, the Warm Springs area was zoned for residential development, including single and multi-family structures in about 1970.

Increasing concern about development in potential avalanche paths led Ketchum to employ two independent consultants to delineate the areas affected by design-magnitude avalanches, defined (Mears, unpublished; Wilson, unpublished) as avalanches with return periods of approximately I00-200 years. Each consulting study defined red and blue zones similar to those of the Vail plan. The city of Ketchum determined that approximately 85 residential lots lie within hazard zones and that approximately 35 of these lots have buildings on them at the present time. The consulting reports recommend that new building be excluded from the red zone and that any building in the blue zone be specially designed for forces resulting from the design avalanche.

The city of Ketchum is divided over the question of whether building should be restricted in defined hazard zones. Those opposing restrictions claim that such restrictions represent an unfair and possibly illegal "taking" of private property, and that it violates the individual's right to do as he wishes with his property. Those in favor of building restrictions similar to 


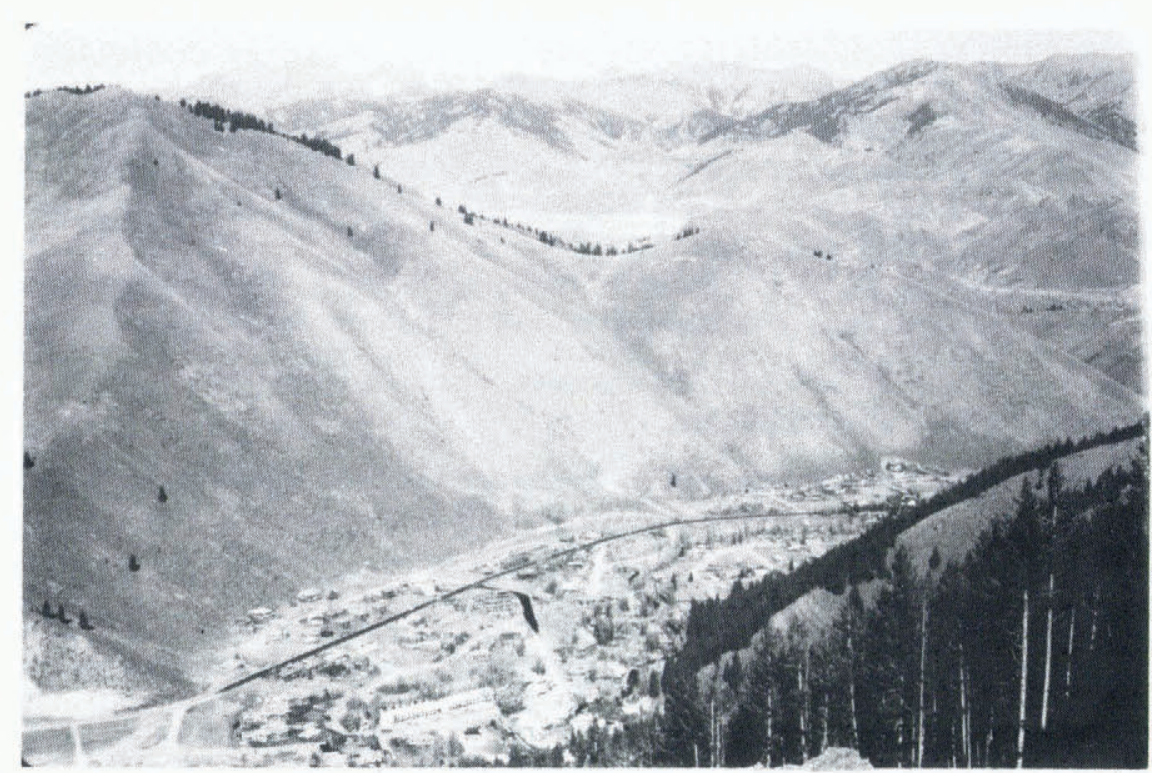

Fig. 3. Warm Springs, Ketchum, Idaho. Smooth, nearly treeless slopes above Warm Springs rise 250-550 $m$ above the developed area. In several locations the run-out zones extend across the road in the photograph that extends nearly parallel to the mountain front.

those of Vail feel that construction in hazard zones is a matter of "public" rather than "private" interest, and feel they have a moral responsibility to protect the public, particularly future owners, tenants, and others who will be unaware of the avalanche hazard if zoning becomes a dead issue.

As a compromise, the following avalanche-zone district is proposed as an addition to the city ordinance with the following provisions:

a. Use restrictions:

All new utilities will be installed underground.

Avalanche-defense structures will not deflect avalanches toward the property of others.

Any structure except a single-family residence will be designed for expected avalanche forces. Design will be certified by an engineer licensed in the State of Idaho who will base his design on avalanche studies done by the city of Ketchum or by an independent consultant recognized by the city as an "expert in the field of avalanche occurrence, force, and behavior".

Any new single-family structure that has not been engineered for avalanche forces will not be leased, rented, or sub-let from ${ }_{15}$ November through ${ }_{15}$ April of each year.

No further subdivision of property intended to create building lots will take place within the high-hazard (red) zone.

b. Notice requirements:

Subdivision plans will identify affected lots as lying within red or blue zones.

Building plans will identify the proposed building as lying within the red or blue zone. 
Building-permit applicant will appear before the city council to receive personal notice of the fact that the proposed building lies within an avalanche-hazard zone.

The city of Ketchum will issue any tenant, lessee, or sub-tenant with written notice that the rented property is in the avalanche zone.

The city of Ketchum will post avalanche-warning signs in the hazard zones on public right of way.

Real-estate agents, salespersons, or brokers, and each private seller inform prospective purchaser with immediate notice that property is in an avalanche zone.

c. Suspension of city services: city services may be suspended during periods of avalanche danger within the avalanche zone.

The Ketchum avalanche-zoning ordinance has not yet been tested in a court of law.

\section{Juneau, Alaska}

Juneau is located at sea-level in a glacial valley in south-eastern Alaska. Large avalanche paths directly above the city rise to an elevation of $900 \mathrm{~m}$ and are subject to widely varying weather and snow-pack conditions resulting from both maritime and continental (Arctic) climatic influences. Several of these large paths threaten parts of the city of Juneau (Fig. 4). Hart (unpublished) reported that six avalanches large enough to reach areas presently developed in Juneau have occurred since I 890 within the large Behrends Avenue avalanche path, indicating an average return period of only 13 years. The most recent major avalanche to affect Juneau occurred in 1962. Excellent documentation of the r 962 avalanche in the Behrends Avenue path (Hart, unpublished) shows that two dozen homes were damaged, including removal of roofs, collapsed walls, broken chimneys and windows, and structural relocation. At present, at least 30 buildings and a large boat dock are exposed to the Behrends Avenue avalanche.

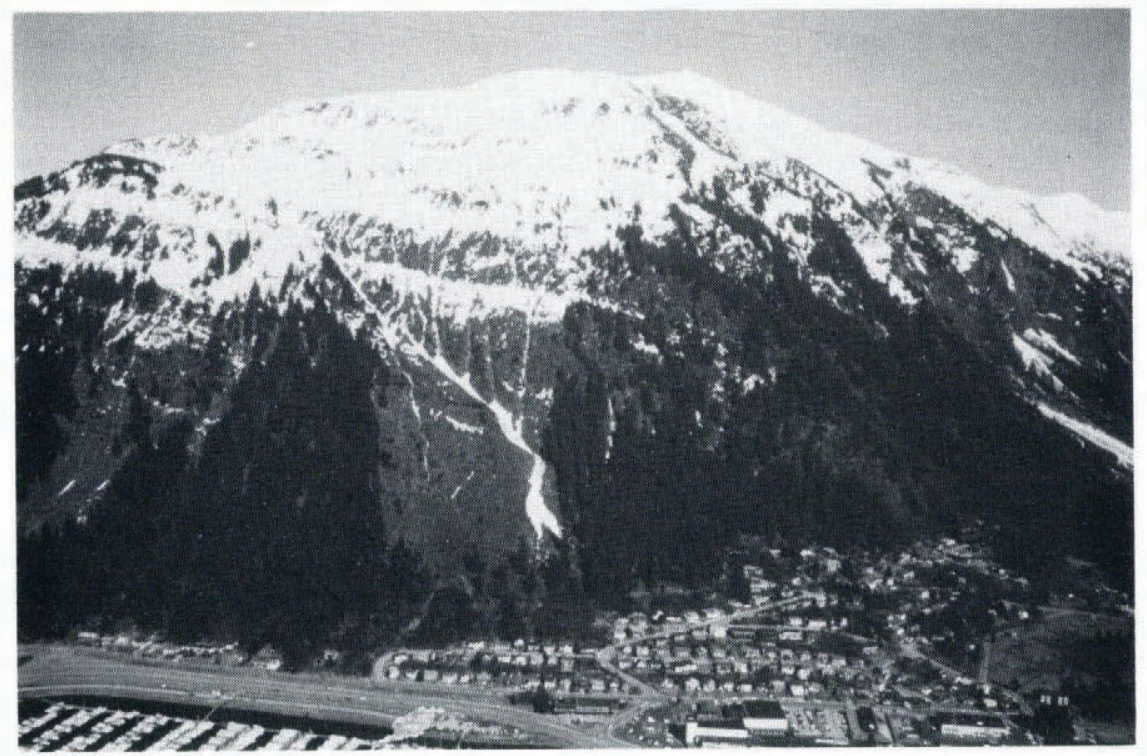

Fig. 4. The large Behrends Avenue avalanche path in Juneau, Alaska, threatens more than 30 buildings and a large boat dock. 
In 1972 , a report of a comprehensive geophysical hazards investigation (Daniel and others, unpublished) was presented to the city and borough of Juneau. As part of this report, avalanche-hazard zones were classified as "high hazard", "potential hazard", and "no hazard", corresponding to hazard categories suggested by Frutiger (1970). The avalanche areas within Juneau were mapped at a scale of $\mathrm{I}$ : 10000 on topographic maps prepared for the study.

The city and borough of Juneau has not restricted land use within the designated avalanche-hazard areas.

\section{Ophir, Colorado}

Ophir is located at an elevation of $3000 \mathrm{~m}$ in the San Juan Mountains of south-western Colorado (Fig. 5). The history of avalanches in Ophir has been described by Ives and others (1976), who recognized that dry- and wet-flowing, and powder avalanches can reach parts of the alluvial fan upon which Ophir is located. This same study provided an avalanche-hazard map (Ives and others, 1976, fig. Io, p. I4I) that is presently used by Ophir to restrict expansion of the town into the run-out zone of the large dry-snow avalanches.

During the period $1976-79$, Ophir residents have become increasingly concerned about the hazard from wet-snow avalanches, which are known to have reached parts of the town in

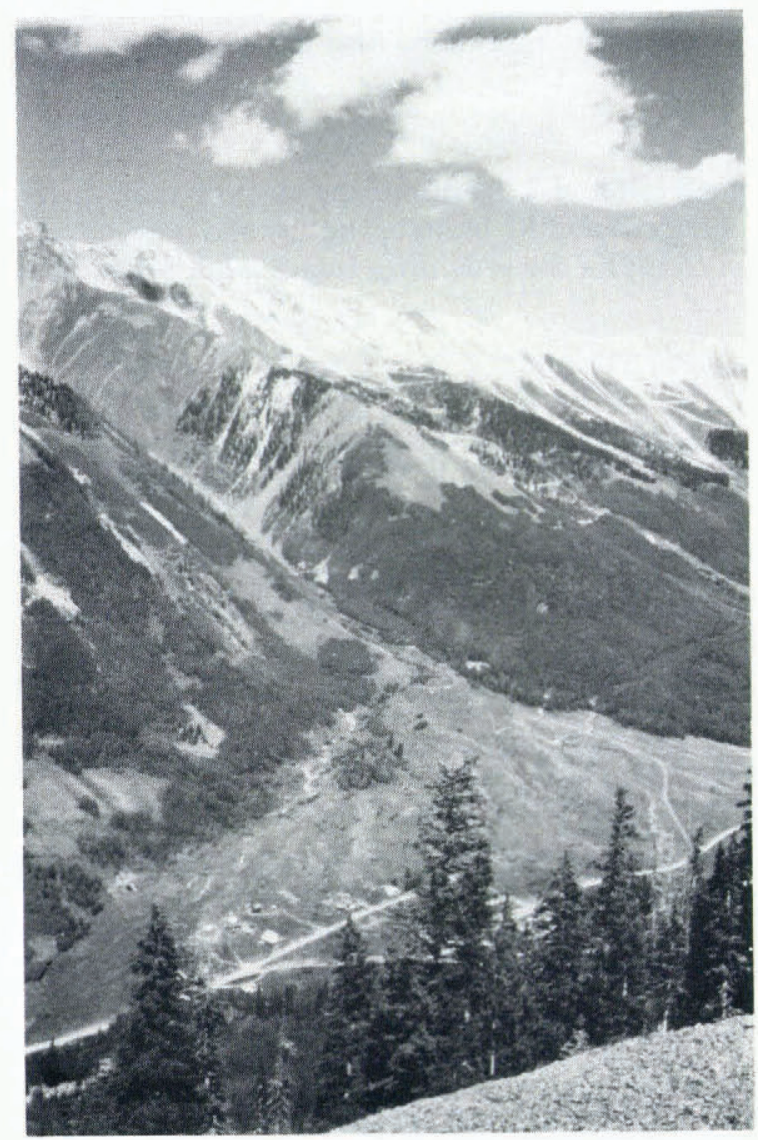

Fig. 5. The Spring Gulch avalanche at Ophir, Colorado, produces dry-snow avalanches that extend completely across the alluvial fan and impact the opposite valley wall. Wet-snow avalanches can reach some of the existing buildings. (Photograph by D. Wolfe.) 
the past (Ives and others, I976). The town of Ophir requested additional detailed information about the dynamic forces associated with wet-snow avalanches because it appears as if this type of avalanche can reach any part of the existing town. This information is being prepared and will apply recently developed U.S. Forest Service research (Martinelli and others, 1980) on the dynamics of wet-snow avalanches, and will compute zones of dynamic-pressure potential in the wet-snow avalanche run-out zones.

Detailed topographic maps of Ophir are not available, thus avalanche-hazard zones will be shown on a large-scale vertical air photograph so that streets, houses, and other prominent physical features can be used as reference points for determining the location of the hazard lines. This procedure has been recommended by Mears (1976).

The wet-snow avalanche hazard to the existing town will be subdivided into two zones of hazard intensity, similar to the hazard zones used in Vail and described above. Recommended land use within the hazard zones will be as follows:

a. In the red (high hazard) zone, new construction should not be permitted.

b. In the blue (moderate hazard) zone building will be permitted, but the town of Ophir will either require or strongly recommend that new structures be designed to accommodate specific dynamic loads.

At the present time it appears most likely that the very small but highly concerned Ophir government will incorporate these regulations into the land-use ordinance.

\section{Acknowledgements}

I wish to thank D. Toughill and J. Rubin of the town of Vail, J. Jaquet and L. Haviik of the city of Ketchum, T. Laurent and R. Janes of the city and borough of Juneau, and D. Wolfe and L. Hart of the town of Ophir for providing information about avalanche zoning.

\section{REFERENCES}

Daniel, P. J., and others. Unpublished. Geophysical hazards investigation for the city and borough of Juneau, Alaska. A summary report, by P. J. Daniel, A. E. Mann, S. K. Johnson, I. F. Mendenhall. [Report to the city and borough of Juneau, 1972.]

Frutiger, H. 1970. Der Lawinenzonenplan (LZP). Schweizerische Zeitschrift für Forstwesen, 12 1. Jahrg., Nr. 4, p. 246-76. [English translation: The avalanche zoning plan. U.S. Dept. of Agriculture. Forest Service. Alta Avalanche Study Center Translation No. I1.]

Hart, K. Unpublished. Report on the Behrends Avenue avalanche path. [Written 1967. Supplement to Daniel and others (unpublished).]

Ives, J. D., and Krebs, P. V. 1978. Natural hazards research and land-use planning responses in mountainous terrain: the town of Vail, Colorado Rocky Mountains, U.S.A. Arctic and Alpine Research, Vol. 10, No. 2, p. $213-22$.

Ives, J. D., and others. 1976. Natural hazards in mountain Colorado, by J. D. Ives, A. I. Mears, P. E. Carrara, and M. J. Bovis. Annals of the Association of American Geographers, Vol. 66, No. 1, p. 129-44.

LaChapelle, E. R. Unpublished. Avalanche mapping and zoning problems at Vail, Colorado. [Report submitted to the town of Vail, 1976.]

Leaf, C. F., and Martinelli, M., jr, ed. 1977. Avalanche dynamics: engineering applications for land use planning. U.S. Dept. of Agriculture. Forest Service. Research Paper RM-183.

Martinelli, M., jr, and others. I 980 . Calculations of avalanche friction coefficients from field data, by M. Martinelli, Jr, T. E. Lang, and A. I. Mears. Journal of Glaciology, Vol. 26, No. 94, p. 109-19.

Mears, A. I. 1976. Guidelines and methods for detailed snow avalanche hazard investigations in Colorado. Colorado. Geological Survey. Bulletin 38.

Mears, A. I. Unpublished. Snow avalanche hazard analysis and zoning recommendations, Warm Springs area, Ketchum, Idaho. [Report to the city of Ketchum, r978.]

Sommerhalder, E. 1966. Lawinenkräfte und Objektschutz. Schnee und Lawinen in den Schweizeralpen. Winterbericht des Eidg. Institutes für Schnee- und Lawinenforschung, Nr. 29, Winter 1964/65, p. 134-41. [English translation: Avalanche forces and the protection of objects. U.S. Dept. of Agriculture. Forest Service. Alta Avalanche Study Center Translation No. 6, I967.] Wilson, N. Unpublished. Avalanche hazard study, the city of Ketchum, Idaho. [Report to the city of Ketchum,
1977.] 